\title{
IMPROVEMENT OF THE ORGANIZATION OF PAYMENTS AT THE ENTERPRISE
}

\author{
Cherep O. G, Dovha K. A., Chernikova N. M. \\ Zaporizhzhia National University \\ Ukraine, 69063, Zaporizhzhia, Zhukovskyi str., 66 \\ cherep2508@gmail.com, karina1999dovga@gmail.com \\ ORCID 0000-0002-3098-0105, ORCID 0000-0003-4095-8232
}

Key words:

remuneration, forms of remuneration, remuneration fund, tariff system, "flexible schedule".

\begin{abstract}
The problem is to improve the organization of wages at the enterprise is quite acute for our country. The urgency is growing against the background of the socioeconomic crisis in the country. An analysis of the organization of wages at the garment factory "Eugenia", a leading enterprise in light industry in Ukraine were done. The structure of the salary fund, the structure of the salary fund by categories of personnel were studied and conclusions about its distribution were made. Forms of remuneration and the current system of remuneration at the enterprise were determined. The features of each of the remuneration systems were indicated. A number of shortcomings in the current pay system at the "Eugenia" garment factory were identified. The focus is on the lack of flexibility of the remuneration system, low productivity and the lack of focus of the system on cooperation. It was established that work motivation should be based on factors that directly depend on employees. A number of proposals have been made to eliminate the identified shortcomings in the current system of labor organization at the "Eugenia" garment factory.
\end{abstract}

\section{ВДОСКОНАЛЕННЯ ОРГАНІЗАЦЇ̈ ПЛАТЕЖІВ НА ПІДПРИЕМСТВІ}

\author{
Череп О. Г., Довга К. А., Чернікова Н. М. \\ Запорізький національний університет \\ Україна, 69000, Запоріжжя, вул. Жуковського, 66
}

\section{Ключові слова:}

винагорода, форми оплати праці, фонд винагороди, тарифна система, "гнучкий графік".
Проблема полягає в тому, щоб поліпшити організацію заробітної плати на підприємстві досить гостро для нашої країни. Актуальність зростає на тлі соціально-економічної кризи в країні. Проведено аналіз організації заробітної плати на швейній фабриці "Євгенія", провідному підприємстві легкої промисловості України. Були вивчені структура фонду заробітної плати, структура фонду заробітної плати за категоріями персоналу та зроблені висновки щодо його розподілу. Визначено форми оплати праці та діючу систему оплати праці на підприємстві. Були вказані особливості кожної із систем оплати праці. Виявлено низку недоліків у діючій системі оплати праці на швейній фабриці "Євгенія". Основна увага приділяється недостатній гнучкості системи оплати праці, низькій продуктивності праці та відсутності зосередженості системи на співпраці. Встановлено, що мотивація праці повинна базуватися на факторах, які безпосередньо залежать від працівників. Внесено низку пропозицій щодо усунення виявлених недоліків нинішньої системи організації праці на швейній фабриці "Свгенія".

\section{Formulation of the problem}

Remuneration is the most important category in the system of working conditions. It, like no other sphere, reflects all the contradictions of society, all the achievements and failures. Proper organization of wages not only creates effective incentives to work, improve its quality, productivity and increase the efficiency of production on this basis, but also directly affects the socioeconomic development of the country and largely determines the living standards of its population.

The problem of wages in the enterprise is one of the most acute. The urgency of the problem increases during the coronavirus pandemic COVID-19.
In Ukraine, there are a number of problems in the system of wage organization: the size of wages is almost detached from the final results of work of employees and enterprises; imperfect wage differentiation; the role of the minimum wage is not defined. All these problems were exacerbated by the payment crisis, which led many companies to wage arrears.

Labor and its payment as values lose their socio-economic purpose, which destroys the foundations of economic and social development of society. This requires comprehensive monitoring, analysis and control of this process in Ukraine. 


\section{Analysis of recent studies and publications}

Recently, much attention has been paid to find optimal forms of remuneration, and hence new approaches to labor management that would be adequate to market relations. This problem is reflected in the research of many domestic and foreign scientists, including Bukareva Y. V. [11], Honcharenko N. H. [1], Hryhorieva O. V. [2], Kovalenko O. V. [3], Kozar K. V. [4], Mikhov L. I. [5], Polishchuk P. V. [6], Potryvaieva N. V. [7], Pryvalova K. V. [3], Syrtseva S. V. [8], Stukalova Y. O. [9], Tertychnyi O. O. [10], Shnurko A. V. [11].

Paying tribute to the scientific and practical significance of the developments and proposals of these authors, it should be noted that the issue of wages at enterprises requires more detailed study and refinement.

\section{Formulation of goals}

The purpose of the work is to consider modern forms and systems of remuneration at the enterprise and ways to improve it.

\section{Presentation of the main research material}

In modern conditions, enterprises use different forms and systems of remuneration, but the most common are three forms of remuneration: piecework, hourly and tariff.

Wages are the most important means of increasing the interest of workers in the results of their work, its productivity, increasing production [6].

Consider the structure of the payroll as the example of the garment factory "Eugenia" (Table 1). The company has three main systems of remuneration: piece-rate bonus, hourly bonus and remuneration depending on the established salary.

Table 1 - The structure of the payroll of the garment factory "Eugenia"

\begin{tabular}{|l|l|l|l|l|l|l|l|l|}
\hline \multirow{2}{*}{ Indicators } & \multicolumn{2}{|c|}{2017} & \multicolumn{2}{c|}{2018} & \multicolumn{2}{c|}{2019} & \multicolumn{2}{c|}{$\begin{array}{c}\text { Deviation 2019 } \\
\text { to 2017 }\end{array}$} \\
\cline { 2 - 10 } & $\begin{array}{c}\text { thousand } \\
\text { UAH }\end{array}$ & $\begin{array}{c}\text { spec. } \\
\text { weight, } \\
\%\end{array}$ & $\begin{array}{l}\text { thousan } \\
\text { d UAH }\end{array}$ & $\begin{array}{c}\text { spec. } \\
\text { weight, } \%\end{array}$ & $\begin{array}{c}\text { thousan } \\
\text { d UAH }\end{array}$ & $\begin{array}{c}\text { spec. } \\
\text { weight, } \\
\%\end{array}$ & $\%$ & $\begin{array}{c}\text { points of } \\
\text { the } \\
\text { structure }\end{array}$ \\
\hline Total wage fund & 12338,6 & 100,0 & 1032,0 & 100,0 & 2132,0 & 100,0 & $-82,7$ & 0 \\
\hline Basic salary & 7221,5 & 58,9 & 607,0 & 58,9 & 1255,0 & 58,9 & $-82,7$ & 0 \\
\hline Additional salary & 5015,1 & 40,9 & 421,7 & 40,9 & 871,1 & 40,9 & $-82,5$ & 0 \\
\hline $\begin{array}{l}\text { Other incentive and } \\
\text { compensation payments }\end{array}$ & 34,4 & 0,3 & 3,1 & 0,3 & 6,2 & 1,0 & $-82,0$ & $-0,7$ \\
\hline
\end{tabular}

According to Table 1 , it is clear that $58.9 \%$, the main part of the payroll, is the basic salary. The basic salary is a reward for the work performed in accordance with established labor standards.

Additional wages aimed at remuneration in excess of the established norms, for labor success, ingenuity and for special working conditions, is $40 \%$ of the total fund.

Other incentive and compensation payments are payments in the form of remuneration for the year, bonuses under special systems and regulations, payments under grants, compensation and other monetary and material payments that are not provided by applicable law or which are made in excess of the established norms. They are only $0.3 \%$.

This structure of the payroll fund of the garment factory "Eugenia" is typical for businesses in this field

The issue of the structure of the payroll by category of staff is quite important, because in the process of planning the payroll must take into account the fact that different categories of employees are charged different amounts of wages (Table 2).

Table 2 - The structure of the payroll by category of personnel of the garment factory "Eugenia".22

\begin{tabular}{|c|c|c|c|c|c|c|c|c|}
\hline \multirow[t]{2}{*}{ Indicators } & \multicolumn{2}{|c|}{$2017 \mathrm{p}}$. & \multicolumn{2}{|c|}{$2018 \mathrm{p}}$. & \multicolumn{2}{|c|}{$2019 \mathrm{p}}$. & \multicolumn{2}{|c|}{$\begin{array}{l}\text { Deviation } 2019 \\
\quad \text { to } 2017\end{array}$} \\
\hline & $\begin{array}{c}\text { thousand } \\
\text { UAH }\end{array}$ & $\begin{array}{c}\text { spec. } \\
\text { weight, } \%\end{array}$ & $\begin{array}{l}\text { thousand } \\
\text { UAH }\end{array}$ & $\begin{array}{c}\text { spec. } \\
\text { weight, } \%\end{array}$ & $\begin{array}{l}\text { thousan } \\
\text { d UAH }\end{array}$ & $\begin{array}{c}\text { spec. } \\
\text { weight, } \%\end{array}$ & $+/-$ & $\%$ \\
\hline Total wage fund & 12338,6 & 100,0 & 1032,0 & 100,0 & 2132,0 & 100 & $-10206,6$ & \\
\hline Management staff, & 1850,8 & 15,0 & 154,8 & 15,0 & 319,8 & 15,0 & $-1531,0$ & $-82,7$ \\
\hline $\begin{array}{l}\text { including: } \\
\text { leaders }\end{array}$ & 740,3 & 6,0 & 63,1 & 6,1 & 129,3 & 6,1 & $-611,0$ & $-82,5$ \\
\hline - specialists & 863,7 & 7,0 & 70,2 & 6,8 & 147,1 & 6,9 & $-716,6$ & $-82,9$ \\
\hline experts & 185,1 & 1,5 & 16,7 & 1,6 & 36,3 & 1,7 & $-144,8$ & $-78,2$ \\
\hline - employees & 61,7 & 0,5 & 4,8 & 0,5 & 7,1 & 0,3 & $-54,6$ & $-88,5$ \\
\hline Production staff & 10487,8 & 85,0 & 877,2 & 85,0 & 1812,2 & 85,0 & $-8675,6$ & $-82,7$ \\
\hline $\begin{array}{l}\text { including: } \\
\text {-main production workers }\end{array}$ & 8266,9 & 67,0 & 701,5 & 68,0 & 1436,4 & 67,4 & $-6830,5$ & $-82,6$ \\
\hline $\begin{array}{|lll|}\text { support and } & \text { service } \\
\text { staff } & & \\
\end{array}$ & 2220,9 & 18,0 & 175,7 & 17,0 & 375,8 & 17,6 & $-1845,1$ & $-83,1$ \\
\hline
\end{tabular}


Table 2 shows that most of the payroll goes to pay the production staff $(68 \%)$, namely the main production workers $(18 \%)$, which is typical for a garment factory. Management staff accounts for $15 \%$ of the payroll.

As already mentioned, remuneration at the "Eugenia"enterprise is carried out in accordance with the unit-based bonus and hourly bonus remuneration systems established in agreement with the trade union committee and with salaries according to the staffing schedule.

The hourly wage system is most advantageous to use if: the company operates production and conveyor lines with a strictly defined rhythm; the functions of the worker are reduced to monitoring and control over the technological process; the costs of determining the planned and accounting for the amount of products produced are relatively high.

The piece-rate bonus is a kind of piece-rate form of remuneration, and consists in the fact that the employee's salary is formed as the product of the price of the number of manufactured products and the coefficient that takes into account the value of the bonus set for certain indicators.

Remuneration of managers and employees is carried out in accordance with salaries. The division of employees by positions is carried out with the help of the Unified Nomenclature (list) of positions and the Qualification Handbook of positions of managers and employees. The directory reflects the qualifications for each position, which consist of three sections: job responsibilities, professional knowledge, qualification requirements [3].

The current remuneration systems of the "Eugenia" garment factory have a number of shortcomings: the increase in wages is not associated with increased efficiency; the current system is not cooperation-oriented; the payment system is not flexible enough; low productivity.

For the current state of the garment factory "Eugenia" are more suitable pay systems based on profit sharing and income distribution. The amount of payments depends on the level of profit, the overall results of production and commercial activities of the garment factory "Eugenia" .When using this system, keep in mind that the increase in profits may depend on market factors and is short-term. Therefore, the rate of profitability is not always the best basis for increasing wages. The system also implies participation in the risk of losses, as the factory is subject to many external, uncontrollable factors.

The income distribution system assumes that bonus payments depend on such indicators as productivity, quality, material savings, reliability.

As a result, the employee may feel a close relationship between the results of their work and the amount of profit.

The first system has a positive effect on attracting of employees and reducing staff turnover, and the second has a greater impact on stimulating productivity, quality, cost reduction. There is an advantage of the income sharing system.

It is necessary to pay attention to piecework bonus payment. At first glance, it is not a disadvantage, but the best solution for the company will be to replace it with a progressive. It will increase the motivation of employees as it provides for the payment of work performed within the established norm, at normal rates, and work performed above the normative level - at higher rates. Therefore, we can say that in addition to increasing employee motivation, labor productivity will also increase.

The next disadvantage is the lack of a "flexible schedule" in the tariff system. This is a negative phenomenon for the "Eugenia" garment factory. If there is a "flexible schedule" in the tariff system, the results of each employee's work are evaluated on a three-point scale and according to the number of points obtained, he can move vertically on the tariff grid in one, two, three rows. Therefore, even within one qualification, everyone has the opportunity to increase their salaries. The use of such a system eliminates the automatic growth of wages without increasing the real skills and productivity of employees.

The further development of the principles laid down in the single tariff grid deserves special attention. This refers to their distribution to the organization of wages of workers and employees of other enterprises and organizations. Experience with the application of the single tariff grid (UTI) shows that certain adjustments may be made in the future. It is a question of quantity of categories of tariffing of works and workers, revision in some cases of assignment of separate works and trades to this or that section provided by ETS [10].

It is necessary to focus the attention of the entire garment factory "Eugenia" on productivity and quality. To do this, you need to determine the requirements for the organization of production: all programs must be executed on time or ahead of schedule; all work must be performed at the lowest cost; all services and works are handed over to customers from the first presentation: quality must come first; you need to use the most advanced technologies, tools and methods. Technology plays an important role. The level of innovation is low, some equipment needs to be replaced, which will increase productivity and quality of all products. Personnel policy should maintain a favorable climate, stability of personnel, the opportunity for their growth.

It should be noted that the system of material interest should be organized as a system of employee investment, tuned to high efficiency objectively by the criterion of evaluation and comparison of results and labor costs. It is advisable to use an approach according to which wages provide a function of investment as labor. The system of material incentives should be focused not on the qualification obtained by the diploma, but on the level of qualification of the work performed or used in decisionmaking. So you can give up hourly wages and pay employees a qualification bonus, rather than the number of man-hours spent at their workplace. Pay incentives for the overall results of the enterprise as a whole.

Therefore, work motivation should be based on factors directly dependent on employees. Non-cost factors may not be independent, because in practice neither sales conditions nor credit conditions really depend on employees. That is why it would be wrong to put employee incentives in direct dependence on profits. Objective accounting and control is necessary, because in this case the company is doomed to non-competitiveness 
with all its consequences. It is absolutely clear that the owner, who is unable to organize proper economic accounting and control, will be forced to give up his place to another, more insistent and consistent in making the company competitive.

\section{Conclusions}

Much attention is paid to the study of the concept of "wages", because it applies to every company where employees work.

A large number of works of economists are devoted to the organization of wages, most of which analyze the peculiarities of the use of various forms and systems of remuneration in modern conditions.

The correct organization of wages can be ensured through the application of the tariff system, scientifically sound labor standards, as well as certain forms and systems of wages.

In the course of the analysis it was determined that in the conditions of functioning of the garment factory "Eugenia" there are three systems of remuneration: piece-rate bonus, hourly bonus and remuneration depending on the established salary.

The current pay systems of the "Eugenia" garment factory have a number of shortcomings.

They can be solved only by introducing changes in the field of staff motivation; replacement of piece-rate premium form of remuneration with piece-rate progressive; introduction of a "flexible schedule" into the tariff system; increasing the level of professionalism of employees.

\section{References}

1. Honcharenko N. H. The need to improve forms and systems of remuneration. URL:http://www.khntusg.com.ua/files/sbornik/vestnik_127/16.pdf

2. Hryhorieva O.V., Shutkina I.S. Application of modern payment systems at the enterprises of Ukraine. Global and national economic problems. 2015. Edition. 5. P. 764-767.

3. Kovalenko O. V., Pryvalova K.V. Improving the system of remuneration at the enterprise Bulletin Zaporizhia State Engineering Academy. 2014 p. 51 - 54.

4. Kozar K. V. Improving the system of remuneration of personnel at the enterprise in modern conditions of small and average business. Technology and design.2017.№ 1 (6). URL:http://er.knutd.com.ua/handle/123456789/1729

5. Mikhov L. I. Improving the system of incentives for workers. Bulletin of Berdyansk University of Management and Business. 2013. № 2. P. 89-94.

6. Polishchuk P. V. Analysis of methods and systems of valuation and remuneration. Bulletin of Khmelnytsky National University. Economic sciences. - 2017. № 3, v. 3. P. 255-258

7. Potryvaieva N. V. Status and prospects of accounting for payroll: a theoretical aspect. Economic forum.2014. № 1. P. 243-249

8. Syrtseva S.V. Problems of accounting for payments to employees in modern conditions. Bulletin of the Black Sea regional scientific-practical conference of faculty. Mykolayiv.2011. P. 133.

9. Stukalova Y. O., Zagorelska T. Yu. Research of modern problems and generalization of the basic directions of improvement of the account of payment. Mukachevo State University. Economy and society. 2018.№19. P. 1350 1357.

10. Tertychny O. O. Modern pay systems. Foreign trade: economics, finance, law. - 2013. - № 2. - P. 62-67.

11. Shnurko A. V., Bukareva Yu. V. The current state of the organization of payroll accounting.2015URL:https://www.sworld.com.ua/konfer41/138.pdf. 